\title{
Influence of Hydrotalcite Containing Corrosion Inhibitormodified by Silane on Corrosion Protection Performance of Epoxy Coating
}

\author{
Nguyen Tuan Anh", Ngo Thi Hoa, To Thi Xuan Hang, \\ Nguyen Thuy Duong, Trinh Anh Truc \\ Institute for Tropical Technology, Vietnam Academy of Science and Technology, \\ 18 Hoang Quoc Viet, Hanoi, Vietnam \\ Received 18 August 2017 \\ Revised 30 August 2017; Accepted 26 October 2017
}

\begin{abstract}
Zinc aluminum hydrotalcite containing 2-benzothiazolythio-succinic acid (HT-BTSA) and modified by 2 -aminoethyl-3-aminopropyltrimethoxysilane (APS) at different concentrations $(3 \%, 5 \%$ and $10 \%)$. APS modified HT-BTSA (HT-BTSA-S) was incorporated in epoxy coatings at $3 \%$ concentration. The corrosion protective performance of the epoxy coatings containing HTBTSA-S were evaluated by electrochemical impedance spectroscopy, adhesion measurement. The results showed that the presence of HT-BTSA-S improved protection performance of epoxy coating and the best protection was obtained with HT-BTSA modified with $5 \%$ APS.
\end{abstract}

Keywords: Epoxy coating, hydrotalcite, silane modification, corrosion inhibitor, corrosion protection.

\section{Introduction}

Organic coatings are widely used for corrosion protection of metal surfaces because they are not expensive and can be easily applied. Chromates are the best corrosion inhibitors for organic coatings, but they are toxic and carcinogenic, so that it is necessary to replace chromates by nontoxic inhibitors. Recently, the use of additives based on hydrotalcites has the attractive attention. Organic coatings containing hydrotalcite intercalated with corrosion inhibitors were studied [1-5]. The effect of hydrotalcites on

\footnotetext{
*Corresponding author. Tel.: 84-936900090.

Email: atndubidaihoc@gmail.com

https://doi.org/10.25073/2588-1140/vnunst.4647
}

protective properties of polymer nanocomposites depends on their dispersion degree in the polymer matrix [6-8]. In order to improve the dispersion of hydrotalcite in polymer matrix, the hydrotalcite surface can be modified by surfactants or silane compounds $[9,10]$.

In our previous studies, hydrotalcites intercalated with 2-benzothiazolylthio-succinic acid (HT-BTSA) was prepared and applied in epoxy coatings. The presence of HT-BTSA improved significantly the corrosion protection of epoxy coating $[11,12]$

In this work, hydrotalcites intercalated with 2-benzothiazolylthio-succinic acid (HT-BTSA) modified by silane at different concentrations were prepared. Corrosion protection of epoxy 
coatings containing silane modified HT-BTSA was evaluated by electrochemical impedance spectroscopy and adhesion measurements.

\section{Experimental}

\subsection{Materials}

Sodium hydroxide, zinc nitrate hexahydrate, $\mathrm{Zn}\left(\mathrm{NO}_{3}\right)_{2} \cdot 6 \mathrm{H}_{2} \mathrm{O}$, aluminum nitrate nonahydrate $\mathrm{Al}\left(\mathrm{NO}_{3}\right)_{3} \cdot 9 \mathrm{H}_{2} \mathrm{O}$, 2-aminoetyl-3aminopropyltrimetoxysilane (APS) were purchased from Merck. Corrosion inhibitor, 2benzothiazolylthio-succinic acid (BTSA) was obtained from Ciba Company. The epoxy resin was epoxy Bisphenol A, Epotec YD 011-X75, epoxy equivalent weight is about $469-490 \mathrm{~g} / \mathrm{eq}$. The hardener PA66 was modified polyamine. Both compounds were purchased from Thai organic chemicals. Co. (Thailand).

\subsection{Preparation of hydrotalcte intercalated with BTSA}

The zinc aluminum hydrotalcite intercalated with BTSA (HT-BTSA) were prepared using the co-precipitation method. A solution of $0.125 \mathrm{~mol}$ of $\mathrm{Zn}\left(\mathrm{NO}_{3}\right)_{2} \cdot 6 \mathrm{H}_{2} \mathrm{O}$ and $0.0625 \mathrm{~mol}$ of $\mathrm{Al}\left(\mathrm{NO}_{3}\right)_{3} .9 \mathrm{H}_{2} \mathrm{O}$ in $125 \mathrm{ml}$ of degassed distilled water were added to a drop wise solution of $0.313 \mathrm{~mol}$ of BTSA with the molar equivalent of $\mathrm{NaOH}$ in $145 \mathrm{ml}$ of degassed distilled water with vigorous mixing under an inert nitrogen atmosphere. The $\mathrm{pH}$ of the solution was maintained at $8-9$ by adding $1 \mathrm{M}$ $\mathrm{NaOH}$ solution. The resultant slurry was aged at $65^{\circ} \mathrm{C}$ for $24 \mathrm{~h}$, cooled to room temperature, and repeatedly washed with large amounts of degassed distilled water before drying at a temperature of $50^{\circ} \mathrm{C}$ for $24 \mathrm{~h}$ in a vacuum oven.

\subsection{Modification of HT-BTSA by 2-aminoethyl- 3-aminopropyltrimethoxysilane}

Solution 2-aminoethyl-3aminopropyltrimethoxysilane in ethanol was added drop wise to solution of HT- BTSA in ethanol. The temperature was maintained at $60^{\circ} \mathrm{C}$ for $6 \mathrm{~h}$. The white precipitate was washed several times with ethanol. HT-BTSA modified modified by silane was dried at $50^{\circ} \mathrm{C}$ in a vacuum oven for $24 \mathrm{~h}$. The HT-BTSA modified by at silane concentration of $3 \%, 5 \%$ and $10 \%$ and the modified HT-BTSAwere named HTBTSA-S3, HT-BTSA-S5 and HT-BTSA-S10 respectively.

\subsection{Preparation of epoxy coatings}

Carbon steel sheets $(150 \mathrm{~mm} \times 100 \mathrm{~mm} \times 2 \mathrm{~mm})$ were used as substrates. The sheets were polished with abrasive papers from 80 to 600 grades and cleaned with ethanol. The hydrotalcites were incorporated in epoxy coating at $3 \%$. The hydrotalcites were incorporated in epoxy resin at $3 \mathrm{wt} \%$, the hadrner was added to the epoxy solution containing hydrotalcite before the application on carbon steel.

The liquid paint was applied by spin coating at $600 \mathrm{rpm}$ for $1 \mathrm{~min}$ and dried at ambient temperature for 7 days. The dry film thickness was $30 \pm 3 \mu \mathrm{m}$ (measured by Minitest 600 Erichen digital meter).

\subsection{Analytical characterizations}

The FTIR spectra were obtained using the $\mathrm{KBr}$ method on a Nexus 670 Nicolet spectrometer operated at $1 \mathrm{~cm}^{-1}$ resolution in the $400-4000 \mathrm{~cm}^{-1}$ region.

Powder X-ray diffraction patterns of synthesized HTs were taken using Siemens diffractometer D5000 with $\mathrm{CuK}_{\alpha}$ radiation $(1.5406$ Á) at room temperature under air conditions.

\subsection{Electrochemical characterization}

The electrochemical impedance measurements were performed using AUTOLAB P30 over a frequency range of 100 $\mathrm{kHz}$ to $10 \mathrm{mHz}$ with six points per decade using $30 \mathrm{mV}$ peak-to-peak sinusoidal voltage. For the electrochemical impedance measurements, a three-electrode cell was used with a large 
platinum auxiliary electrode, a saturated calomel reference electrode (SCE) and a working electrode with an exposed area of $12.56 \mathrm{~cm}^{2}$. The corrosive medium was the $3 \%$ $\mathrm{NaCl}$ solution.

\subsection{Adhesion measurement}

The adhesion strength of the coatings was determined according to ASTM D4541 by a PosiTest digital Pull-Off adhesion tester (DeFelsko) with $20 \mathrm{~mm}$ dollies. The experiments involved pulling dollies affixed by a 2-part AralditTM Epoxy adhesive away from the coated substrate. The maximum force by which the dolly lifts the coating from the steel plate was recorded as a measure of the bond strength between the coating and the substrate.

\section{Results an discussion}

\subsection{Characterization of HT-BTSA modified by APS}

HT-BTSA modified by APS was characterized by FT-IR spectroscopy and XRD. Figure. 1 shows the FT-IR spectra APS, HTBTSA, HT-BTSA-S3, HT-BTSA-S5 and HTBTSA-S10.

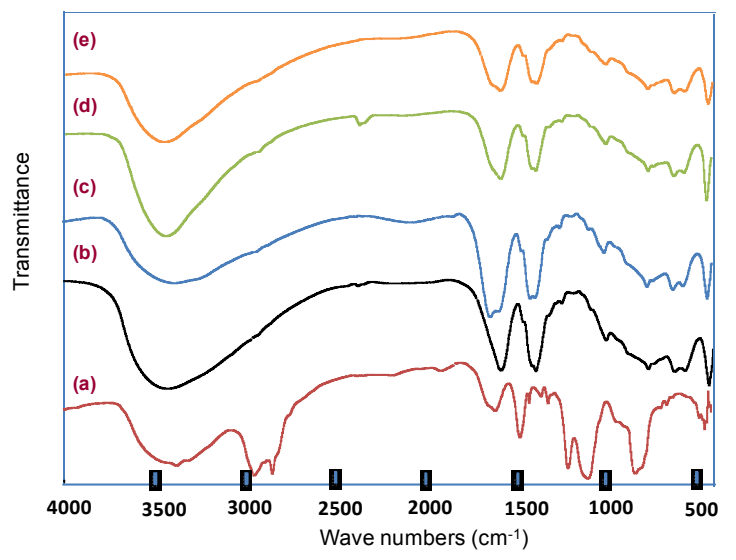

Fig. 1. FT-IR spectra of APS (a), HT-BTSA (b), HT-BTSA-S3 (c), HT-BTSA-S5 (d) and HT-BTSA-S10 (e).
The spectrum of APS shows a band at 3370 $\mathrm{cm}^{-1}$ characteristic of $-\mathrm{OH}$ and $-\mathrm{NH}_{2}$ groups. The bands at $2940 \mathrm{~cm}^{-1}$ and $2840 \mathrm{~cm}^{-1}$ are attributed to the vibration of $-\mathrm{CH}_{3}$ and $-\mathrm{CH}_{2}$ groups. The band at $1083 \mathrm{~cm}^{-1}$ is relative to Si$\mathrm{O}$ vibration and characteristic band at $818 \mathrm{~cm}^{-1}$ originates from the symmetric stretch of $\mathrm{Si}-\mathrm{O}$ $\mathrm{CH}_{3}[13]$.

The spectrum of HT-BTSA displays the characteristic peaks of hydrotalcite at $423 \mathrm{~cm}^{-1}$, $630 \mathrm{~cm}^{-1}$. It is observed also the characteristic peak of $\mathrm{COO}^{-}$at $1580 \mathrm{~cm}^{-1}$ and $1423 \mathrm{~cm}^{-1}$.

The spectra of HT-BTSA-S present peaks characteristic of HT-BTSA at $1383 \mathrm{~cm}^{-1}$ và $1580 \mathrm{~cm}^{-1}$ which are attributed to $-\mathrm{NO}_{3}$ và $\mathrm{COO}^{-}$groups. Beside that spectra of HTBTSA-S show peaks characteristic of Si-O-Al, $\mathrm{Si}-\mathrm{O}-\mathrm{Zn}$ at $994 \mathrm{~cm}^{-1}$. These results indicate that APS has been successfully grafted onto the HTBTSA surface.

Figure. 2 shows the XRD patterns of HTBTSA, HT-BTSA-S3, HT-BTSA-S5 and HTBTSA-S10. The XRD patterns of the HT-BTSA exhibit the (003) reflection corresponding to the basal spacing of hydroxide layer of 1.73 $\mathrm{nm}$, which is higher than the value of zinc aluminum nitrate hydrotalcite of $0.79 \mathrm{~nm}$ [12]. The higher d-spacing values of the HT-BTSA by comparison with this value of nitrate hydrotalcite show that molybdate were intercalated in the interlayer domain and replaced $\mathrm{NO}_{3}{ }^{-}$anion. The XRD pattern of HTBTSA-S3 has the peaks corresponding to the dspacing of $0.82 \mathrm{~nm}$ and $1.66 \mathrm{~nm}$, similarly to the one of HT-BTSA. This results indicate that in the case of HT-BTSA-S3, the APS was grafted on the external surface of hydrotalcite. For HT-BTSA-S5 and HT-BTSA-S10 the interlayer distance were slightly increased. The increase of interlayer distance of HT-BTSA-S5 and HT-BTSA-S10 shows that the APS was not only grafted on the external surface but also intercalated between hydroxide layers of hydrotalcites. 


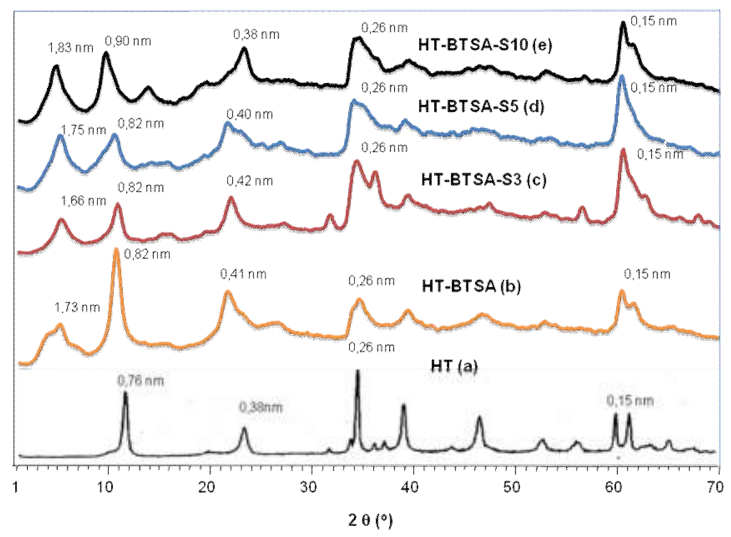

Fig. 2. XRD patterns of HT (a), HT-BTSA (b), HTBTSA-S3 (c), HT-BTSA-S5 (d) và HT-BTSA-S10 (e).

\subsection{Electrochemical impedance measurements}

EIS measurements were carried out to evaluate the corrosion resistance of the carbon steel covered by the pure epoxy coating and epoxy coating containing HT-BTSA, epoxy coating containing HT-BTSA-S3, epoxy coating containing HT-BTSA-S5 and epoxy coating containing HT-BTSA-S10 at three concentrations $3 \%$ during immersion time in 3 wt. $\% \mathrm{NaCl}$ solution. The impedance diagrams obtained after 28 days exposure to $3 \% \mathrm{NaCl}$ solution are presented in Fig 3.

After 28 days immersion in $3 \% \mathrm{NaCl}$ solution, the EIS diagram of pure epoxy coating presented two circles well defined. This indicates that electrolyte penetrated in the coating and the corrosion process occurred at metal surface. For epoxy coatings containing HT-BTSA, HT-BTSA-S the second cycles at low frequencies were not determined. These results shows that for this coatings electrolyte were not reached the metal surface and the corrosion process did not begin. The impedance modulus of epoxy coating containing HTBTSA and HT-BTSA-S were higher than this value of pure epoxy coating. Among coatings containing hydrotalcite, coating containing HTBTSA-S5 had highest impedance modulus.

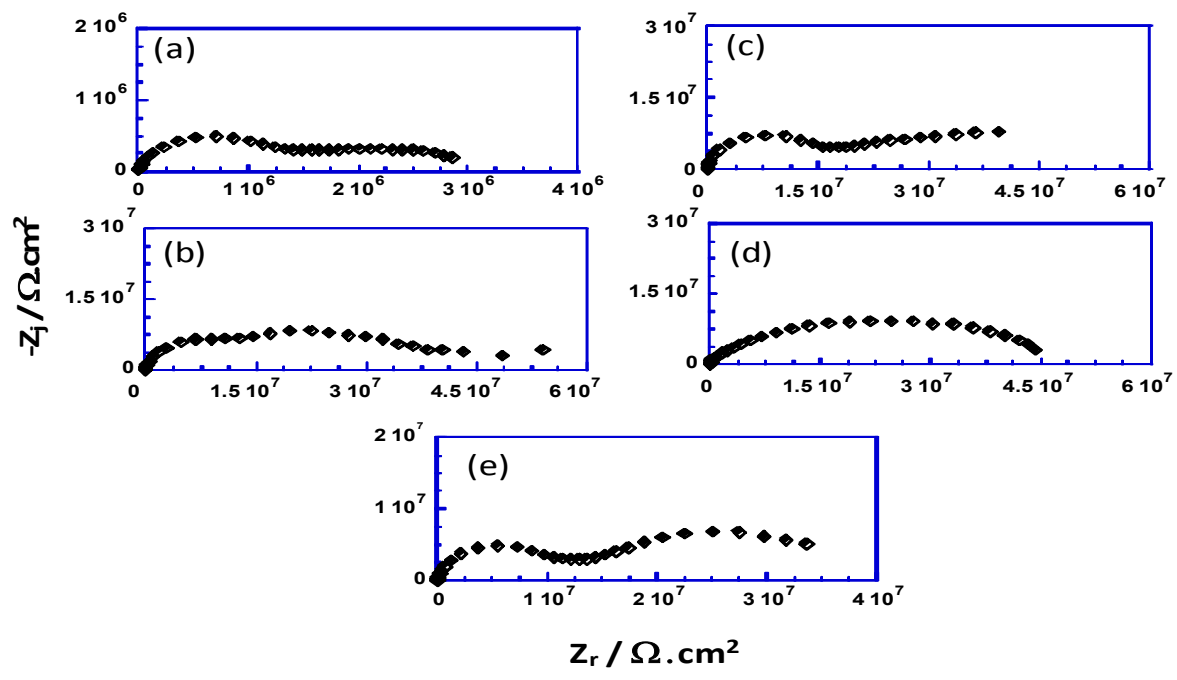

Fig. 3. Electrochemical impedance diagrams obtained after 28 days exposure to $3 \% \mathrm{NaCl}$ solution for the carbon steel covered by pure epoxy coating (a), epoxy coating containing 3\% hydrotalcite: HT-BTSA (b), HT-BTSA-S3 (c), HT-BTSA-S5 (d) and HT-BTSA-S10 (e).

According to literature, the impedance modulus at low frequency, between 1 and 0.01 $\mathrm{Hz}$, is an appropriate parameter for characterization of corrosion protection of coatings $[14,15]$. The impedance modulus at low frequency of $10 \mathrm{mHz}, Z_{10 \mathrm{mHz}}$ were extracted from impedance diagrams, were used to follow the degradation of coatings with 
exposure time in the aggressive solution. The variation of $\mathrm{Z}_{10 \mathrm{mHz}}$ values with immersion time in $\mathrm{NaCl} 3 \%$ solution are presented in Fig. 4.

At the beginning, the $Z_{10 \mathrm{mHz}}$ values of all coatings were very high and these values of coatings containing hydrotalcite were higher than the one of pure epoxy coating. During the first 7 days of immersion the $Z_{10 \mathrm{mHz}}$ values of pure epoxy coatings decreased rapidly, while these values of coatings containing hydrotalcite decreased progressively. The decrease of $\mathrm{Z}_{10 \mathrm{mHz}}$ values was due to penetration of water and electrolyte in the coatings. After 28 days of exposure, the $Z_{10 \mathrm{mHz}}$ values of coating containing HT-BTSA and coating containing HT-BTSA modified by APS were higher than the one of pure epoxy coating. The $Z_{10 \mathrm{mHz}}$ values containing HT-BTSA modified by APS were higher than the one of epoxy coating containing HT-BTSA. Among coatings containing APS modified HT-BTSA, the epoxy coating containing HT-BTSA-S5 had highest $\mathrm{Z}_{10 \mathrm{mHz}}$ values. The results indicate that the presence of HT-BTSA improved the corrosion protection performance of epoxy coating and modified by silane improved the effect of HTBTSA. The best protection was obtained with the HT-BTSA-S3.

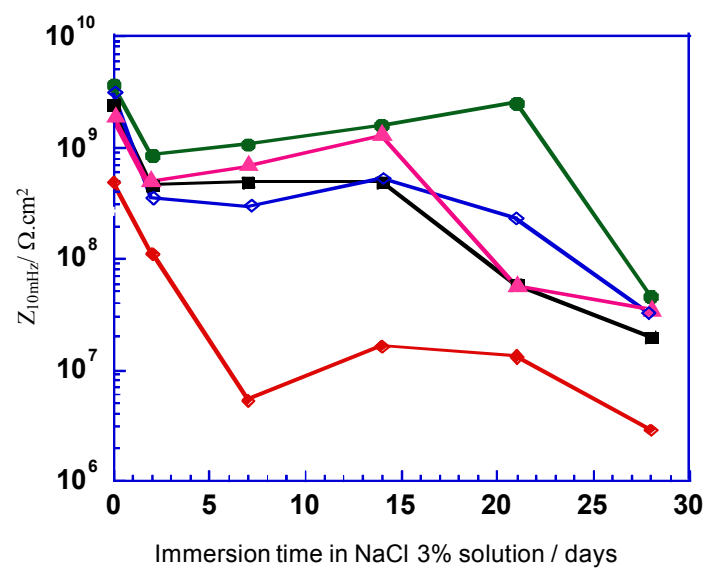

Fig. 4. Variation of $\mathrm{Z}_{10 \mathrm{mHz}}$ values with immersion time in $\mathrm{NaCl} 3 \%$ solution of pure epoxy coating $(\diamond)$, epoxy coating containing 3\% hydrotalcite: HT-BTSA (匹),

$$
\text { HT-BTSA-S3 }(\diamond) \text {, HT-BTSA-S5 }(\bullet)
$$
and HT-BTSA-S10 ( $\boldsymbol{\Delta})$
Beside impedance measurement the adhesion of coatings was evalusated (Table 1). It is observed that the adhesion of epoxy coatings containing HT-BTSA is closed to the one of pure epoxy coating. Among coatings containing APS modified HT-BTSA, the coating with HT-BTSA-S3 and HT-BTSA-S5 has higher adhesion strength by comparison with coating containing HT-BTSA. The increase of coating adhesion with the presence of HT-BTSA modified by APS can be explained by the interaction of APS with the steel surface. These adhesion results are in agreement with the impedance measurement.

Table 1. Adhesion strength of coatings

\begin{tabular}{ll}
\hline \multicolumn{1}{c}{ Sample } & $\begin{array}{l}\text { Adhesion } \\
\text { strength } \\
\left(\mathrm{N} / \mathrm{mm}^{2}\right)\end{array}$ \\
\hline $\begin{array}{l}\text { Pure epoxy coatings } \\
\text { Epoxy coating containing 3\% }\end{array}$ & 0.7 \\
$\begin{array}{l}\text { HT-BTSA } \\
\text { Epoxy coating containing 3\% }\end{array}$ & 0.7 \\
$\begin{array}{l}\text { HT-BTSA-S3 } \\
\text { Epoxy coating containing 3\% }\end{array}$ & 0.8 \\
$\begin{array}{l}\text { HT-BTSA-S5 } \\
\text { Epoxy coating containing 3\% } \\
\text { HT-BTSA-S10 }\end{array}$ & 0.7 \\
\hline
\end{tabular}

\section{Conclusions}

Zinc aluminum hydrotalcite containing 2benzothiazolythio-succinic acid (HT-BTSA) and modified by 2-aminoethyl-3aminopropyltrimethoxysilane (APS) were successfully prepared. The presence of HTBTSA and silane modified HT-BTSA improved corrosion resistance epoxy coating. Surface modification by APS enhanced protection efficiency of HT-BTSA on epoxy coatings and the best protection performance was obtained with HT-BTSA modified by $3 \%$ APS.

\section{Acknowledgments}

This research was funded by the Vietnam National Foundation for Science and 
Technology Development (NAFOSTED) under grant number 104.01-2012.15. The authors gratefully acknowledge the support of Vietnam Academy of Science and Technology and ThaiFrench Innovation Institute.

\section{References}

[1] Williams G., McMurray HN. Inhibition of Filiform Corrosion on Polymer Coated AA2024T3 by Hydrotalcite-Like Pigments Incorporating Organic Anions, Electrochem. Solid-State Lett 7 (2004) B13-B15.

[2] Zheludkevich M.L., Poznyak S.K., Rodrigues L.M., Raps D., Hack T., Dick L.F., Nunes T., Ferreira M.G.S. Active protection coatings with layered double hydroxide nanocontainers of corrosion inhibitor. Corrosion Science 52 (2010) 602-611.

[3] Xiang Yu, Jun Wang, Milin Zhang, Lihui Yang, Junqing Li, Piaoping Yang, Dianxue Cao. Synthesis, characterization and anticorrosion performance of molybdate pillared hydrotalcite/in situ created $\mathrm{ZnO}$ composite as pigment for $\mathrm{Mg}-\mathrm{Li}$ alloy protection. Surface and Coatings Technology 203 (2008) 250-255.

[4] Kendig M., Hon M. A hydrotalcite-like pigment containing an organic anion corrosion inhibitor. Electrochemical and Solid- State Letters 8 (2005) B10-B11.

[5] Poznyak S.K., Tedim J., Rodrigues L.M., Salak A.N., Zheludkevich M.L., Dick L.F.P., Ferreira M.G.S. Novel Inorganic Host Layered Double Hydroxides Intercalated with Guest Organic Inhibitors for Anticorrosion Applications. ACS Applied Materials \& Interfaces 1 (2009) 2353-2362.

[6] Troutier-Thuilliez, AL, Taviot-Guého, C, Cellier, J, Hintze-Bruening, H, Leroux, F,. Layered particle-based polymer composites for coatings:
Part I. Evaluation of layered double hydroxides. Prog. Org. Coat. 64 182-192 (2009).

[7] Hintze-Bruening, $H$, Troutier-Thuilliez, AL, Leroux, F,. Layered particle-based polymer composites for coatings: Part II-Stone chip resistant automotive coatings. Prog. Org. Coat., 64 193-204 (2009)

[8] Lv, S, Zhou, W, Miao, H, Shi, W,. Preparation and properties of polymer/LDH nanocomposite used for UV curing coatings. Prog. Org. Coat., 65 450-456 (2009).

[9] Tao, Q, Yuan, J, Frost, RL, He, H, Yuan, P, Zhu, J,. Effect of surfactant concentration on the stacking modes of organo-silylated layered double hydroxides. Applied Clay Science 45 262-269 (2009).

[10] Tao, Q, He, H, Frost, RL, Yuan, P, Zhu, J, Nanomaterials based upon silylated layered double hydroxides. Applied Surface Science 255 4334-4340 (2009).

[11] Hang T. T. X., Truc T. A., Duong N. T., Pébère N., Olivier M. G. Layered double hydroxides as containers of inhibitors in organic coatings for corrosion protection of carbon steel. Prog. Org. Coat. 74 (2012) 343-348.

[12] Hang T. T. X., Truc T. A., Duong N. T., Vu P. G., Hoang T. Preparation and characterization of nanocontainers of corrosion inhibitor based on layered double hydroxides. Appl. Clay Sci. 67 (2012) 18-25

[13] Z. Guo, S. Wei, B. Shedd, R. Scaffaro, T. Pereira and H.T. Hahn. J. Mater. Chem. 17 (2007) 806-813.

[14] Kittel J., Celati N., Keddam M., Takenouti H. Influence of the coating-substrate interactions on the corrosion protection: characterisation by impedance spectroscopy of the inner and outer parts of a coating. Prog. Org. Coat., 46 (2003) 135-147.

[15] Bierwagen G. P., Tallman D., Li J., He L., Jeffcoate C. EIS studies of coated metals in accelerated exposure. Prog. Org. Coat. 46 (2003) 148-158. 


\title{
Ảnh hưởng của Hydrotanxit mang ức chế ăn mòn biến tính bằng Silan đến hiệu suất bảo vệ ăn mòn của màng Epoxy
}

\author{
Nguyễn Tuấn Anh, Ngô Thi Hoa, Tô Thị Xuân Hằng, \\ Nguyễn Thùy Dương, Trịnh Anh Trúc \\ Viện Kỹ thuật Nhiệt đới - Viện Hàn lâm Khoa học và Công nghệ Việt Nam, \\ 18 Hoàng Quốc Việt, Hà Nội, Việt Nam
}

Tóm tắt: Hydrotalcit $\mathrm{Zn}$-Al mang axit 2-benzothiazolythio-succinic (HT-BTSA) và được biến tính bằng 2-aminoethyl-3-aminopropyltrimethoxysilane (APS) tại các nồng độ khác nhau $(3 \%, 5 \%$ and $10 \%$ ). HT-BTSA biến tính APS (HT-BTSA-S) được đưa vào màng epoxy với nồng độ $3 \%$. Hiệu suất bảo vệ ăn mòn của màng epoxy chứa HT-BTSA-S được đánh giá bằng phổ tổng trở điện hóa và đo độ bám dính. Kết quả chỉ ra rằng sự có mặt của HT-BTSA-S đã cải thiện khả năng bảo vệ cho màng epoxy và khả năng bảo vệ tốt nhất thu được với màng epoxy chứa HT-BTSA biến tính APS $5 \%$.

Tù khóa: Màng epoxy, hydrotanxit, biến tính silan, ức chế ăn mòn, bảo vệ ăn mòn. 